\title{
Health and Welfare Awareness of Rice and Vegetable Farmers
}

\author{
Maria Petra O. Ebron, Rexces James D. Lopez, Percival O. Ebron \\ Agribusiness Department, Partido State University, Camarines Sur, Philippines \\ Email: rexcesjames.lopez@parsu.edu.ph
}

How to cite this paper: Ebron, M.P.O., Lopez, R.J.D. and Ebron, P.O. (2021) Health and Welfare Awareness of Rice and Vegetable Farmers. Open Access Library Journal, 8: e7890.

https://doi.org/10.4236/oalib.1107890

Received: August 25, 2021

Accepted: November 12, 2021

Published: November 15, 2021

Copyright $\odot 2021$ by author(s) and Open Access Library Inc.

This work is licensed under the Creative Commons Attribution International License (CC BY 4.0).

http://creativecommons.org/licenses/by/4.0/ (c) (i) Open Access

\begin{abstract}
Farmers suffer from injuries and diseases due to extreme pesticide exposure and inadequate knowledge on farming health-safety behaviors. This study focused on developing health and welfare awareness of farmers towards conventional pesticide application. It aimed to identify the level of farmers' awareness of the negative effects and preventive use of pesticides. One hundred and seventy-five rice and vegetable farmers' respondents were sampled randomly from selected barangays of San Jose, Camarines Sur. Combinations of internationally published qualitative and quantitative research methods were utilized in this study including survey, interview, and focus group discussion using a standardized questionnaire. The data gathered were tabulated and analyzed by means of descriptive statistics. Findings revealed that farmers who had long exposure to pesticides suffer from skin and respiratory diseases. The majority of the farmers were aware of the health hazards caused by pesticides but refused to wear personal protective gear due to convenience and cost-availability factors. It was suggested that training on proper usage of Personal Protective Equipment (PPE) and health welfare awareness campaign must be conducted through extension services by SUC's and the Department of Agriculture in collaboration with the Rural Health Unit of San Jose, Camarines Sur.
\end{abstract}

\section{Subject Areas}

Agriculture, Health

\section{Keywords}

Awareness, Pesticide, Hazards, Health, Personal Protective Equipment, Safety

\section{Introduction}

The Philippine Constitution recognizes the responsibility of the state not only to 
manage, develop and conserve the Agricultural resources but also to protect the rights of the citizen and the proper utilization. Specifically, the Article 9 Section 12 of 1987 Philippine Institutions adheres that the state shall establish and maintain an effective food and drug regulatory system and undertake appropriate health, manpower development, and research, responsive to the country's health needs and problems [1].

Unfortunately, the farmers' health is at great risk due to too much exposure to toxic substances used in farming. If not given intervention on human capital like proper health care services, training on latest agricultural practices adaptable to rapid environmental changes and other services for sustainable agriculture, shortage of food supply will likely happen [2]. In rural areas, farmers lack access to health services due to financial constraints. Farmers are now becoming slim in number particularly the new generation who prefer to engage in white-collar jobs. In addition, youth negatively perceived agriculture as not profitable because most of the farming activities are portrayed to be difficult and assumed to be meant for ageing rural population [3].

Food security and environmental safety have been given a primary focus by the agricultural sector due to increasing population growth across countries. Pesticides have been widely used to sustain the food production as it keeps pest that causes serious damage in agriculture sector when it comes to yield and production [4]. Pesticide is biologically active compounds that contain specific inherent toxicity used to prevent undesired organism like fungi, weeds and insects [5]. The Food and Agriculture Organization (FAO), states that there is a loss of around $50 \%$ of the annual production in developing countries and accounts that $20 \%$ of its global market are highly dependent on pesticides which are expected to increase in the coming years [6].

Farm laborers who have direct involvement in pesticide mixing and application pose a serious danger to their health [7]. The hazardous effects of a high-toxic pesticide can be divided into three categories that include acute symptoms, chronic, and allergic ill-effects that may arise from short to long term and from mild to acute level because of direct exposure through respiration, ingestion and skin contact [8].

Around three million cases of chronic poisoning are accounted worldwide annually that occur because of acute pesticide poisoning wherein two million are suicide attempts, and the remaining are accidental or occupational poisoning [9]. In most cases, farmers who have great exposure suffer from health diseases due to lack of good agricultural practices such as unmaintained and inappropriate spraying equipment, inadequate storage practices, usage of left-over pesticides, banned toxic chemicals application and improper usage of personal protective equipment due to the lack of awareness [10].

Developing countries based their family's health and well-being in terms of health and productivity of its workforce since professional health is considered as sustainable development in societies. In the agricultural sector of Iran, health 
has greater emphasis since agriculture is recognized as a high-risk business worldwide where almost 1.3 billion of its country's labor force is engaging in farming [11]. Moreover, farmers suffer from injuries and diseases due to their low awareness and lack of adequate education particularly on farming health and safety behaviour [12].

This paper aimed to identify the level of farmers' knowledge towards negative effects of conventional farming on human health, to assess the farmers' awareness on the safe use of pesticides and field spraying practices that might potentially expose them to chemical hazards and to determine the possible intervention in mitigating the health hazards caused by conventional farm chemicals and pesticides.

\section{Materials and Methods}

This study was conducted in the town of San Jose, Camarines Sur where rice and vegetable farming is the main livelihood. This study had a total of 175 respondents where 91 were rice farm laborers who are directly exposed to pesticides. They were from barangays Catalotoan, Calalahan, Mampirao and Bagacay. Eighty four (84) were hands-on vegetable farmers from barangays Ponglon, Tagas, Telegrafo and Salogon. The following barangays were chosen to be the respondents of the study since majority of them are engaging into rice and vegetable farming listed by the Municipal Agriculture Office of San Jose.

The study utilized descriptive-comparative design since it emphasizes the development of health and welfare awareness of farmers towards conventional pesticide. Descriptive method is appropriate to be used because it describes the awareness level of farmers to the use of pesticides, effects of pesticides and the use of protective gear. The comparative method of research was used in assessing the levels of awareness and participation of male and female on the use of pesticides and protective gear in farms [13].

This study used purposive sampling design using Sloven's Formula and ratio and proportion for rice farming and total enumeration for the vegetable farming. The data were gathered through the use of standardized survey questionnaire and interview reinforced by focus group discussion to validate the responses. The interview method presents detailed answers and provides respondent's independence of fluency [14]. Focus group discussion method is deliberate to be more elastic and as a result provides to examine in-depth information about the group's attitudes, perceptions and experiences on a clear topic [15]. The data were tabulated and analyzed using the statistical tools such as: frequency, percentage, and weighted mean.

The survey questionnaire used in this study was conceptualized based on the published literature on Assessment of Farmers' Awareness on the Safety and Health Implications on the use of Agrochemicals [16]. The first part of the questionnaire includes the socio-demographic, farming characteristics, and farming 
practices of the respondents. Finally, a checklist-scale was used to gauge the farmers' level of awareness towards the negative effects conventional pesticide.

The mean score was computed after farmers' responses to each question or statements were obtained using the five point type likert scale such as: $1=$ Strongly Disagree (SDA), $2=$ Disagree (DA), $3=$ Neutral $(\mathrm{N}), 4=$ Agree $(\mathrm{A})$, and $5=$ Strongly Agree (SA). These were used to assign weight for each item on the questionnaire. Also, the mean score was used to identify the most challenging area.

The mean response to each question was interpreted using the concepts of real limits of numbers. The numerical value of the scale points and their respective real limits are listed below:

Strongly Agree $(\mathrm{SA})=5$ point with real limits of $4.50-5.49$.

Agree $(\mathrm{A})=4$ point with real limits of $3.50-4.49$.

Neutral $(\mathrm{N})=3$ point with real limits of $2.50-3.49$.

Disagree $(\mathrm{DA})=2$ point with real limits of $1.50-2.49$.

Strongly Disagree $(\mathrm{SDA})=1$ point with real limits of $0.5-1.49$.

For the decision rule, any mean score below 3.0 was interpreted as a serious challenge to farmer's use of PPE and knowledge or awareness level of health implications of agrochemical use. Likewise, any mean score more than 3.0 was considered as not a challenge. The study compared the result with reviewed literature that is related with the theme of the study. In the process of interpretation, the Fuctionalist Approach of Talcott Parsons to highlight that good health and effective medical care are vital for society's ability to function [17]. Conclusions for an innovative knowledge can be attained in a research study if there is consistency in the knowledge base and the theory [18].

\section{Results and Discussion}

\subsection{Socio-Demographic and Farming Characteristics of Rice-Farmers}

Table 1 showed that the personal characteristics of the rice-farmer respondents were majority male with $57 \%$ ranging from 50 years old and above. In terms of educational level, majority were high school graduate with $54 \%$. In terms of farming practices, majority are engaging into rice farming for more than 10 years with $63 \%$. Most lease the land which accounts to $39 \%$, with a size ranging from half to one hectare with $32 \%$. Rice farming served as the primary source of income of the respondents with $78 \%$ for the purpose of both selling and personal consumption that corresponds to $76 \%$. Despite this, $56 \%$ were not affiliated with farmer's association or cooperative. It was observed that most of the farmers who are engaging in rice farming are dominated by aged men and few are young. This means that these small scale farmers who did not reach tertiary education seemed to shift into farming as primary livelihood. However, there were still college graduates and some professionals who are attracted to pursue farming as business and sustain the farming industry [19]. 
Table 1. Socio-demographic and farming characteristics of rice farmers.

\begin{tabular}{|c|c|c|}
\hline \multicolumn{3}{|c|}{ Rice Farmers' Personal Characteristics } \\
\hline Characteristics & $\mathrm{F}$ & $\mathbf{P}$ \\
\hline \multicolumn{3}{|l|}{ Gender } \\
\hline Male & 52 & $57 \%$ \\
\hline Female & 39 & $43 \%$ \\
\hline \multicolumn{3}{|l|}{ Age (Years) } \\
\hline $20-30$ & 0 & $0 \%$ \\
\hline $31-40$ & 11 & $12 \%$ \\
\hline $41-50$ & 31 & $34 \%$ \\
\hline 51 above & 49 & $54 \%$ \\
\hline \multicolumn{3}{|l|}{ Education } \\
\hline No formal Education & 0 & $0 \%$ \\
\hline Elementary Graduate & 24 & $26 \%$ \\
\hline High School Graduate & 49 & $54 \%$ \\
\hline Skilled/Vocational Graduate & 7 & $8 \%$ \\
\hline College Graduate & 11 & $12 \%$ \\
\hline \multicolumn{3}{|c|}{ Farming Characteristics of Rice Farmers } \\
\hline Characteristics & F & $\mathbf{P}$ \\
\hline \multicolumn{3}{|l|}{ Farming Experience (Years) } \\
\hline Less than 3 & 4 & $4 \%$ \\
\hline 3 to 5 & 11 & $12 \%$ \\
\hline 6 to 10 & 19 & $21 \%$ \\
\hline More than 10 & 57 & $63 \%$ \\
\hline \multicolumn{3}{|l|}{ Land Ownership } \\
\hline Own all & 34 & $37 \%$ \\
\hline Lease all & 35 & $39 \%$ \\
\hline Part Own/Part Lease & 22 & $24 \%$ \\
\hline \multicolumn{3}{|l|}{ Size of Agricultural Land } \\
\hline No Land & 10 & $11 \%$ \\
\hline Less than Half a Hectare & 21 & $23 \%$ \\
\hline 0.5 - 1 Hectare & 29 & $32 \%$ \\
\hline 1 - 2 Hectare & 26 & $29 \%$ \\
\hline 2 - 3 Hectares & 3 & $3 \%$ \\
\hline More than 3 & 2 & $2 \%$ \\
\hline \multicolumn{3}{|l|}{ Purpose of Rice Farming } \\
\hline For Selling & 7 & $7 \%$ \\
\hline For Personal Consumption & 15 & $16 \%$ \\
\hline
\end{tabular}


Continued

\begin{tabular}{ccc}
\hline Both & 69 & $76 \%$ \\
Affiliations to Famers' Association & & \\
Member & 40 & $44 \%$ \\
Non-member & 51 & $56 \%$ \\
Rice Farming as Source of Income & 71 & $78 \%$ \\
Primary & 20 & $22 \%$ \\
Secondary/Alternative & 20 \\
\hline
\end{tabular}

\subsection{Socio-Demographic and Farming Characteristics of Vegetable Farmers}

Table 2 showed that the personal characteristics of the vegetable-farmer respondents were dominated by male with $75 \%$ ranging from 50 years old and above. In terms of educational level, majority of them are high school graduate with $56 \%$. Majority were engaging into vegetable farming for more than 10 years with $53 \%$. Most lease the land they farm and majority ranging a size of less than half a hectare. It also showed the farming practices of vegetable farmer respondents in which majority were engaging into vegetable farming for more than 10 years with $53 \%$ but not affiliated into farmers' association or cooperative with $58 \%$. Vegetable farming served as the primary source of income of the respondents with $89 \%$ where in their main purpose is for both selling and personal consumption that corresponds to $75 \%$. Looking at the results, it can be interpreted that majority are engaging into farming for more than decades but still lease the land they farm. It was also observed that vegetable farming served as a substitute source of income of farmers whenever the weather season is not suitable for rice farming.

\subsection{Awareness on Pesticide Usage}

Table 3 showed the awareness of rice and vegetable farmers when it comes to the use of pesticide. In Table 3(a), rice farmer respondents were in Neutral Agreement (NA) in terms of awareness on pesticide usage with 2.30 weighted mean. $24 \%$ of the rice farmer respondents Strongly Disagreed (SDA) that they were aware of policies or methods that have been established to strengthen pesticide risk reduction. Table 3(b) showed the vegetable farmer respondents Neutrally Agreed (NA) that they were aware about proper usage of pesticide with 3.00 weighted mean. $30 \%$ of vegetable farmers Agreed (A) to Strongly Agreed (SA) that they were aware of policy or methods that have been established to strengthen pesticide risk reduction.

The results showed that both rice and vegetable farmer respondents were Neutrally Aware (NA) how to properly use and apply pesticide. However, a larger percentage of rice farmers do not adhere to the prohibitions and guidelines of using pesticides. During the conduct of the survey, it was noticed there was no 
Table 2. Socio-demographic and farming characteristics of vegetable farmers.

\begin{tabular}{|c|c|c|}
\hline \multicolumn{3}{|c|}{ Vegetable Farmers' Personal Characteristics } \\
\hline Characteristics & $\mathbf{F}$ & $\mathbf{P}$ \\
\hline \multicolumn{3}{|l|}{ Gender } \\
\hline Male & 63 & $75 \%$ \\
\hline Female & 21 & $25 \%$ \\
\hline \multicolumn{3}{|l|}{ Age (Years) } \\
\hline $20-30$ & 4 & $5 \%$ \\
\hline $31-40$ & 22 & $26 \%$ \\
\hline $41-50$ & 23 & $27 \%$ \\
\hline 51 above & 35 & $42 \%$ \\
\hline \multicolumn{3}{|l|}{ Education } \\
\hline No formal Education & 1 & $1 \%$ \\
\hline Elementary Graduate & 23 & $27 \%$ \\
\hline High School Graduate & 47 & $56 \%$ \\
\hline Skilled/Vocational Graduate & 8 & $10 \%$ \\
\hline College Graduate & 5 & $6 \%$ \\
\hline \multicolumn{3}{|c|}{ Farming Characteristics of Vegetable Farmers } \\
\hline Characteristics & $\mathrm{F}$ & $\mathbf{P}$ \\
\hline \multicolumn{3}{|l|}{ Farming Experience (Years) } \\
\hline Less than 3 & 3 & $4 \%$ \\
\hline 3 to 5 & 9 & $11 \%$ \\
\hline 6 to 10 & 27 & $32 \%$ \\
\hline More than 10 & 45 & $53 \%$ \\
\hline \multicolumn{3}{|l|}{ Land Ownership } \\
\hline Own all & 12 & $14 \%$ \\
\hline Lease all & 38 & $45 \%$ \\
\hline Part Own/Part Lease & 34 & $41 \%$ \\
\hline \multicolumn{3}{|l|}{ Size of Agricultural Land } \\
\hline No Land & 3 & $3 \%$ \\
\hline Less than Half a Hectare & 29 & $35 \%$ \\
\hline 0.5 - 1 Hectare & 27 & $32 \%$ \\
\hline 1 - 2 Hectare & 13 & $15 \%$ \\
\hline 2 - 3 Hectares & 4 & $5 \%$ \\
\hline More than 3 & 8 & $10 \%$ \\
\hline \multicolumn{3}{|l|}{ Purpose of Vegetable Farming } \\
\hline For Selling & 16 & $19 \%$ \\
\hline For Personal Consumption & 5 & $6 \%$ \\
\hline Both & 63 & $75 \%$ \\
\hline \multicolumn{3}{|l|}{ Affiliations to Famers' Association } \\
\hline Member & 49 & $58 \%$ \\
\hline
\end{tabular}




\section{Continued}

\begin{tabular}{ccc}
\hline Non-member & 35 & $42 \%$ \\
Vegetable Farming as Source of Income & & \\
Primary & 75 & $89 \%$ \\
Secondary/Alternative & 9 & $11 \%$ \\
\hline
\end{tabular}

Table 3. Awareness on pesticides usage of rice and vegetable farmers' respondents. (a) Awareness on pesticide usage of rice farmers; (b) Awareness on pesticide usage of vegetable farmers.

(a)

\begin{tabular}{|c|c|c|c|c|c|}
\hline & 5 & 4 & 3 & 2 & 1 \\
\hline I am aware that conventional pesticides have negative effects on my health. & $55 \%$ & $13 \%$ & $21 \%$ & $7 \%$ & $4 \%$ \\
\hline I am confident that I can use PPE properly. & $24 \%$ & $25 \%$ & $29 \%$ & $14 \%$ & $8 \%$ \\
\hline I am unprotected when not using correct PPE. & $24 \%$ & $22 \%$ & $32 \%$ & $15 \%$ & $7 \%$ \\
\hline I have a strong knowledge and training to use PPE properly. & $13 \%$ & $12 \%$ & $42 \%$ & $13 \%$ & $20 \%$ \\
\hline $\begin{array}{l}\text { I have been suffering respiratory diseases such as cough cold, asthma, breathlessness, } \\
\text { and chest pain due to pesticide application. }\end{array}$ & $13 \%$ & $15 \%$ & $26 \%$ & $9 \%$ & $36 \%$ \\
\hline $\begin{array}{l}\text { I am strongly aware about the guidance document exists on safe and environmentally } \\
\text { sound disposal of agricultural pesticide waste. }\end{array}$ & $18 \%$ & $12 \%$ & $22 \%$ & $12 \%$ & $36 \%$ \\
\hline I am aware about policy or methods that have been established to strengthen pesticide risk reduction. & $18 \%$ & $19 \%$ & $23 \%$ & $16 \%$ & $24 \%$ \\
\hline I adhere to the prohibition on the use of pesticide. & $27 \%$ & $31 \%$ & $23 \%$ & $13 \%$ & $5 \%$ \\
\hline I know sufficient resources and expertise in applying pesticides. & $16 \%$ & $33 \%$ & $31 \%$ & $12 \%$ & $8 \%$ \\
\hline I feel comfortable when using PPE. & $21 \%$ & $21 \%$ & $32 \%$ & $14 \%$ & $12 \%$ \\
\hline I regularly visit health centers for check up. & $4 \%$ & $4 \%$ & $16 \%$ & $23 \%$ & $52 \%$ \\
\hline Weighted mean & 2.30 & 2.10 & 2.96 & 1.5 & 2.1 \\
\hline
\end{tabular}

(b)

\begin{tabular}{|c|c|c|c|c|c|}
\hline & 5 & 4 & 3 & 2 & 1 \\
\hline I am aware that conventional pesticides have negative effects on my health. & $51 \%$ & $24 \%$ & $18 \%$ & $1 \%$ & $6 \%$ \\
\hline I am confident that I can use PPE properly. & $31 \%$ & $27 \%$ & $27 \%$ & $7 \%$ & $7 \%$ \\
\hline I am unprotected when not using correct PPE. & $46 \%$ & $23 \%$ & $19 \%$ & $6 \%$ & $6 \%$ \\
\hline I have a strong knowledge and training to use PPE properly. & $14 \%$ & $23 \%$ & $26 \%$ & $14 \%$ & $23 \%$ \\
\hline $\begin{array}{l}\text { I have been suffering respiratory diseases such as cough cold, asthma, breathlessness, } \\
\text { and chest pain due to pesticide application. }\end{array}$ & $17 \%$ & $19 \%$ & $20 \%$ & $26 \%$ & $18 \%$ \\
\hline $\begin{array}{l}\text { I am strongly aware about the guidance document exists on safe and environmentally } \\
\text { sound disposal of agricultural pesticide waste. }\end{array}$ & $36 \%$ & $25 \%$ & $14 \%$ & $10 \%$ & $15 \%$ \\
\hline I am aware about policy or methods that have been established to strengthen pesticide risk reduction. & $30 \%$ & $30 \%$ & $25 \%$ & $5 \%$ & $10 \%$ \\
\hline I adhere to the prohibition on the use of pesticide. & $45 \%$ & $26 \%$ & $21 \%$ & $1 \%$ & $6 \%$ \\
\hline I know sufficient resources and expertise in applying pesticides. & $17 \%$ & $42 \%$ & $26 \%$ & $4 \%$ & $12 \%$ \\
\hline I feel comfortable when using PPE. & $40 \%$ & $23 \%$ & $13 \%$ & $10 \%$ & $14 \%$ \\
\hline I regularly visit health centers for check up. & $8 \%$ & $12 \%$ & $23 \%$ & $12 \%$ & $45 \%$ \\
\hline Weighted mean & 3.00 & 2.44 & 2.09 & 0.85 & 1.46 \\
\hline
\end{tabular}


Integrated Pest Management implemented in the community and majority do not visit health centers for consultation except in cases of severe illness.

\subsection{Awareness on Effects of Pesticide}

Table 4 presented the farmer respondents level of awareness when it comes to effects of pesticides to human health. In Table 4(a), majority of rice farmers respondents Disagree (DA) that they are suffering from negative effects on health with 1.80 weighted mean. However, $22 \%$ of rice farmers responded that they were experiencing burning sensation in eyes and face due to contact to pesticides. As shown in Table 4(b), majority of vegetable farmer respondents Disagreed (DA) that they have been experiencing headache, fever, decrease in weight, loss of appetite, vomiting, and abdominal pain with 1.67 weighed mean. On the other hand, thirty-one (31\%) of the vegetable farmer respondents is in agreement that they are suffering from dizziness and weakness.

Looking at the gathered data, there was a higher percentage of rice farmers who experience negative health effects caused by pesticide rather than vegetable farmers. It was observed that more than half of the vegetable farmer respondents of Barangay Telegrafo, San Jose, Camarines Sur were suffering from headache, dizziness, eye and skin irritation, and respiratory diseases since most of them are already old and have been exposed to conventional pesticide for a longer period of time. Low-dose and long-term contact to pesticide may increase the risk of respiratory illnesses like asthma [20]. In addition, the farmers do not have

Table 4. Awareness on effects of pesticide to rice and vegetable farmers' health. (a) Awareness of pesticide effects to rice farmers' health; (b) Awareness of pesticide effects to vegetable farmer's health.

(a)

\begin{tabular}{|c|c|c|c|c|c|}
\hline & 5 & 4 & 3 & 2 & 1 \\
\hline I have been experiencing burning sensation in the eyes and face due to contact to pesticides. & $22 \%$ & $12 \%$ & $14 \%$ & $20 \%$ & $32 \%$ \\
\hline I have been experiencing dizziness or sudden weakness caused by too much exposure to conventional pesticides. & $11 \%$ & $16 \%$ & $21 \%$ & $24 \%$ & $27 \%$ \\
\hline I have suffering from abrupt change on my physical well-being such as weight, loss of appetite, and or loss of libido. & $7 \%$ & $12 \%$ & $25 \%$ & $22 \%$ & $34 \%$ \\
\hline I have been experiencing headache and fever. & $4 \%$ & $12 \%$ & $19 \%$ & $23 \%$ & $42 \%$ \\
\hline I have been experiencing vomiting salivation, abdominal pain and or diarrhoea due to exposure to pesticide. & $9 \%$ & $13 \%$ & $15 \%$ & $20 \%$ & $43 \%$ \\
\hline Weighted mean & 0.5 & 0.7 & 0.9 & 1.1 & 1.8 \\
\hline
\end{tabular}

(b)

\begin{tabular}{|c|c|c|c|c|c|}
\hline & 5 & 4 & 3 & 2 & 1 \\
\hline I have been experiencing burning sensation in the eyes and face due to contact to pesticides. & $23 \%$ & $17 \%$ & $26 \%$ & $17 \%$ & $18 \%$ \\
\hline I have suffering from abrupt change on my physical well being such as weight, loss of appetite, and or loss of libido. & $12 \%$ & $15 \%$ & $24 \%$ & $23 \%$ & $26 \%$ \\
\hline I have been experiencing headache and fever. & $15 \%$ & $12 \%$ & $15 \%$ & $17 \%$ & $40 \%$ \\
\hline I have been experiencing vomiting salivation, abdominal pain and or diarrhoea due to due to exposure to pesticide. & $6 \%$ & $8 \%$ & $17 \%$ & $11 \%$ & $58 \%$ \\
\hline Weighted mean & 0.63 & 0.83 & 1.05 & 0.82 & 1.67 \\
\hline
\end{tabular}


first-aid training given by any government institution regarding the basic treatment if cases of irritation and suffocation happen. As immediate response, farmers tend to wash the affected area with clean water.

\subsection{Precautionary Measures on Pesticide Application}

Table 5 showed the level of awareness of both rice and vegetable farmers on the use of precautionary gears and protective measures in applying pesticide. With weighted mean of 2.19 , it can be interpreted that the rice farmer respondents were in Disagreement (DA) in wearing PPE and practicing pre-preventive measures in pesticide application.

Table 5(b) showed that the rice farmer respondents neutrally disagree (NDA) that they are following precautionary measures in pesticide application with 2.61 weighted mean. Thirty-one percent (31\%) of the vegetable farmers responded

Table 5. Precautionary measures on the use of pesticide in rice and vegetable farming. (a) Precautionary measures on the use of pesticide in rice farming; (b) Precautionary measures on the use of pesticide in vegetable farming.

(a)

\begin{tabular}{|c|c|c|c|c|c|}
\hline & 5 & 4 & 3 & 2 & 1 \\
\hline I am practicing precautionary measure before pesticide application. & $21 \%$ & $15 \%$ & $30 \%$ & $19 \%$ & $15 \%$ \\
\hline I am using PPE when applying pesticide. & $22 \%$ & $18 \%$ & $31 \%$ & $16 \%$ & $13 \%$ \\
\hline My working gear is protecting me enough when using harmful chemicals. & $26 \%$ & $23 \%$ & $27 \%$ & $11 \%$ & $12 \%$ \\
\hline I always wear the prescribed attire when spraying on the farm. & $11 \%$ & $16 \%$ & $33 \%$ & $19 \%$ & $21 \%$ \\
\hline I always wear shoes on the farm to protect my feet. & $10 \%$ & $10 \%$ & $11 \%$ & $14 \%$ & $55 \%$ \\
\hline I always protect my eyes with goggle when spraying pesticides. & $21 \%$ & $15 \%$ & $9 \%$ & $18 \%$ & $37 \%$ \\
\hline I always wear gloves to protect my hands when at work. & $16 \%$ & $16 \%$ & $15 \%$ & $19 \%$ & $33 \%$ \\
\hline I always wear respiratory devices when handling harmful chemicals. & $22 \%$ & $22 \%$ & $14 \%$ & $16 \%$ & $25 \%$ \\
\hline I am following instructions/the user manual reflected on the pesticide that I am using. & $48 \%$ & $21 \%$ & $16 \%$ & $8 \%$ & $7 \%$ \\
\hline Weighted mean & 1.98 & 1.57 & 1.87 & 1.40 & 2.19 \\
\hline
\end{tabular}

(b)

\begin{tabular}{|c|c|c|c|c|c|}
\hline & 5 & 4 & 3 & 2 & 1 \\
\hline I am practicing precautionary measure before pesticide application. & $31 \%$ & $31 \%$ & $23 \%$ & $5 \%$ & $11 \%$ \\
\hline I am using PPE when applying pesticide. & $23 \%$ & $15 \%$ & $26 \%$ & $6 \%$ & $30 \%$ \\
\hline My working gear is protecting me enough when using harmful chemicals. & $29 \%$ & $21 \%$ & $15 \%$ & $12 \%$ & $23 \%$ \\
\hline I always wear the prescribed attire when spraying on the farm. & $15 \%$ & $17 \%$ & $23 \%$ & $18 \%$ & $27 \%$ \\
\hline I always wear shoes on the farm to protect my feet. & $12 \%$ & $6 \%$ & $23 \%$ & $7 \%$ & $52 \%$ \\
\hline I always protect my eyes with goggle when spraying pesticides. & $12 \%$ & $11 \%$ & $31 \%$ & $10 \%$ & $37 \%$ \\
\hline I always wear gloves to protect my hands when at work. & $14 \%$ & $14 \%$ & $25 \%$ & $10 \%$ & $37 \%$ \\
\hline I always wear respiratory devices when handling harmful chemicals. & $20 \%$ & $10 \%$ & $25 \%$ & $13 \%$ & $32 \%$ \\
\hline I am following instructions/the user manual reflected on the pesticide that I am using. & $44 \%$ & $14 \%$ & $19 \%$ & $11 \%$ & $12 \%$ \\
\hline Weighted mean & 2.00 & 1.39 & 2.10 & 0.90 & 2.61 \\
\hline
\end{tabular}


Agree to Strongly Agree (A-SA) that they were practicing precautionary measure before applying pesticides.

As shown in Table 5, rice-farmers have higher level of awareness on the use of precautionary measures than the vegetable farmer. During the focus group discussion, it was noticed that a shirt or a piece of cloth served as an improvised mask of the farmers while sunglasses served as their improvised goggles. Unfortunately, some are constantly using these protective gears but some are not religiously using them despite knowing the health risks of pesticide. Also, it was found-out that majority of rice and vegetable farmers do not use gloves and shoes since they do not feel comfortable on using them due to muddy farm. Lack of farming personal protective equipment, poor equipment maintenance, poor knowledge and human errors are some identified factors contributing to ill-health and injuries [21].

\subsection{Preventive Measures during and after Pesticide Application of Rice and Vegetable Farmers}

Table 6 showed the precautionary measures of rice and vegetable farmers during and after application of pesticides. Given the weighted mean of 3.90, rice farmer respondents were in Agreement (A) that they are practicing preventive measures

Table 6. Rice and vegetable farmers' preventive measures during and after pesticide application. (a) Rice-farmers' preventive measures during and after pesticide application; (b) Vegetable-farmers' preventive measures during and after pesticide application.

(a)

\begin{tabular}{|c|c|c|c|c|c|}
\hline & 5 & 4 & 3 & 2 & 1 \\
\hline I do not eat during pesticide application. & $63 \%$ & $10 \%$ & $13 \%$ & $10 \%$ & $4 \%$ \\
\hline I do not drink any beverages or even water during application. & $63 \%$ & $15 \%$ & $7 \%$ & $5 \%$ & $10 \%$ \\
\hline I do not smoke during application. & $70 \%$ & $10 \%$ & $8 \%$ & $3 \%$ & $9 \%$ \\
\hline I religiously wash my hands during application. & $71 \%$ & $12 \%$ & $10 \%$ & $4 \%$ & $2 \%$ \\
\hline I do not use left-over pesticide solution. & $56 \%$ & $20 \%$ & $15 \%$ & $5 \%$ & $3 \%$ \\
\hline I do not use left-over pesticide in drinking containers. & $67 \%$ & $11 \%$ & $15 \%$ & $2 \%$ & $4 \%$ \\
\hline Weighted mean & 3.90 & 0.78 & 0.68 & 0.31 & 0.33 \\
\hline
\end{tabular}

(b)

\begin{tabular}{|c|c|c|c|c|c|}
\hline & 5 & 4 & 3 & 2 & 1 \\
\hline I do not eat while applying pesticide. & $69 \%$ & $7 \%$ & $7 \%$ & $5 \%$ & $12 \%$ \\
\hline I do not drink any beverages or even water during application. & $68 \%$ & $13 \%$ & $6 \%$ & $4 \%$ & $10 \%$ \\
\hline I do not smoke during application. & $70 \%$ & $8 \%$ & $10 \%$ & $4 \%$ & $8 \%$ \\
\hline I religiously wash my hands during application. & $73 \%$ & $10 \%$ & $4 \%$ & $7 \%$ & $7 \%$ \\
\hline I do not use left-over pesticide solution. & $50 \%$ & $15 \%$ & $15 \%$ & $7 \%$ & $12 \%$ \\
\hline I do not use left-over pesticide in drinking containers. & $63 \%$ & $10 \%$ & $7 \%$ & $6 \%$ & $14 \%$ \\
\hline Weighted mean & 3.93 & 0.63 & 0.49 & 0.32 & 0.63 \\
\hline
\end{tabular}


during and after pesticide application as shown in Table 6(a). Majority of the vegetable agreed $(\mathrm{A})$ that they were practicing preventive measures during and after pesticide application with a weighted of 3.93 in Table 6(b).

Despite knowing the hazards of pesticides, farmers refused to use PPE for they are not comfortable of using them. It was noticed that farmers were not aware about the specific protective gear for farming because these were not introduced to them in a form of training. Another reason was the availability and expensive prices of these PPE. Furthermore, farmers revealed that they did not have proper training on Integrated Pest Management, Proper Usage, Basic First Aid Training. Instead, they learned the process of applying pesticide from chemical demonstration. Proper usage of personal protective equipment and information concerning personal hygiene after pesticide use shall be introduced [22].

\subsection{Awareness on Storage of Pesticides of Rice and Vegetable Farmer}

Table 7 showed the Awareness of Rice and Vegetable Farmers in terms of pesticide storage. In Table 7(a), rice farmer respondents had high awareness level in terms of proper storage, disposal and sanitation of hazardous farm chemicals with 3.6 weighted mean. Likewise, Table 7 (b) presented that majority of the vegetable farmers had high level of awareness on the proper storage, disposal and sanitation of hazardous farm chemicals with a weighted mean of 3.89. However, it was found-out that there was no recorded incidence of chemical

Table 7. Rice and vegetable farmers' awareness on pesticide storage. (a) Rice farmers' awareness on storage of pesticides; (b) Vegetable farmers' awareness on storage of pesticides.

(a)

\begin{tabular}{|c|c|c|c|c|c|}
\hline & 5 & 4 & 3 & 2 & 1 \\
\hline The chemical storage is free from slip and leakage causes. & $71 \%$ & $16 \%$ & $5 \%$ & $4 \%$ & $2 \%$ \\
\hline The pesticides are kept on a designated storage that can't be reached by children. & $78 \%$ & $12 \%$ & $3 \%$ & $4 \%$ & $2 \%$ \\
\hline Chemicals spill on the storage floor were clean immediately. & $75 \%$ & $14 \%$ & $7 \%$ & $1 \%$ & $3 \%$ \\
\hline I regularly clean and keep the tools after completion of spraying. & $79 \%$ & $11 \%$ & $7 \%$ & $0 \%$ & $3 \%$ \\
\hline I properly dispose the pesticides container in a proper area. & $62 \%$ & $16 \%$ & $7 \%$ & $2 \%$ & $13 \%$ \\
\hline Weighted mean & 3.6 & 0.7 & 0.3 & 0.1 & 0.2 \\
\hline
\end{tabular}

(b)

\begin{tabular}{|c|c|c|c|c|c|}
\hline & 5 & 4 & 3 & 2 & 1 \\
\hline The chemical storage is free from slip and leakage causes. & $71 \%$ & $8 \%$ & $15 \%$ & $1 \%$ & $4 \%$ \\
\hline The pesticides are kept on a designated storage that can't be reached by children. & $89 \%$ & $5 \%$ & $4 \%$ & $0 \%$ & $2 \%$ \\
\hline Chemicals spill on the storage floor were clean immediately. & $76 \%$ & $15 \%$ & $8 \%$ & $0 \%$ & $0 \%$ \\
\hline I regularly clean and keep the tools after completion of spraying. & $75 \%$ & $14 \%$ & $5 \%$ & $2 \%$ & $4 \%$ \\
\hline I properly dispose the pesticides container in a proper area. & $77 \%$ & $10 \%$ & $8 \%$ & $2 \%$ & $1 \%$ \\
\hline Weighted mean & 3.89 & 0.54 & 0.40 & 0.06 & 0.11 \\
\hline
\end{tabular}


poisoning in the area due to improper storage except for suicidal attempts. In order to prevent pesticide toxicity, it recommended and certified pesticides from approved sources should be used by skilled hands and must follow adequate precautions [23]. It is imperative to enhance the level of the farmer's knowledge through trainings, workshops, and information dissemination to improve the pesticide handling and storage practice [24].

\section{Conclusions and Recommendations}

The study revealed that rice and vegetable farmers were aware that too much exposure to pesticide would lead health hazards. Findings showed that old farmers who had long farming experience suffered from illness as compared to young farmers who had less exposure to pesticides. Despite knowing the negative effects of conventional pesticide, the majority refused to wear personal protective equipment for they are not comfortable using them. Farmers had poor knowledge of farming protective gears since these were not introduced to their locality. It has been a practice of some farmers to use shirt or a piece cloth as an improvised mask while sunglasses served as their improvised goggles. Furthermore, it was found out that farmers practiced preventive measures during and after pesticide application by not eating, drinking, and smoking. Frequent washing of hand with soap and proper pesticide storage were also observed.

The result of the study significantly established the need to conduct training to farmers on the proper usage of farming personal protective equipment by State Universities and Colleges and Department of Agriculture. It is recommended that Health and Welfare Awareness Orientation Campaign and Annual Check-Up must be conducted to the farmers by the Rural Health Unit of San Jose. Moreover, this study will serve as a baseline for the Local Government Unit to implement an ordinance or policy that will require farmers to use personal protective equipment.

\section{Conflicts of Interest}

The authors declare no conflicts of interest.

\section{References}

[1] Chan, J. (2021) 1987 Constitution of the Republic of the Philippines. Chan Robles Virtual Law Library. https://www.chanrobles.com/article13health.htm

[2] Rein, B. (1992) Health Hazards in Agriculture-An Emerging Issue. https://nasdonline.org/1246/d001050/health-hazards-in-agriculture-an-emerging-is $\underline{\text { sue.html }}$

[3] Njeru, L. and Karega, L. (2017) Youth in Agriculture; Perceptions and Challenges for Enhanced Participation in Kajiado North Sub-County, Kenya Youth in Agriculture; Perceptions and Challenges for Enhanced Participation in Kajiado North SubCounty, Kenya. Greener Journal of Agricultural Sciences, 7, 203-209. http://doi.org/10.15580/GJAS.2017.8.100117141

[4] Chattopadhyay, P., Banerjee, G. and Mukherjee, S. (2017) Recent Trends of Modern 
Bacterial Insecticides for Pest Control Practice in Integrated Crop Management System. 3 Biotech, 7, Article No. 60. https://doi.org/10.1007/s13205-017-0717-6

[5] Claeys, L., De Voghel, S., Schmit, J., Vromman, V. and Pussemier, L. (2008) Exposure of Several Belgian Consumer Groups to Pesticide Residues through Fresh Fruit and Vegetable Consumption. Food Additives and Contaminants. Part A, 25, 851-863. https://doi.org/10.1080/02652030701854741

[6] Murphy, H., Hoan, N., Matteson, P. and Abubakar, A. (2002) Farmers' Self-Surveillance of Pesticide Poisoning: A 12-Month Pilot in Northern Vietnam. International Journal of Occupational and Environmental Health, 8, 201-211.

[7] Soares, W. and Porto, M. (2009) Estimating the Social Cost of Pesticide Use: An Assessment from Acute Poisoning in Brazil. Ecological Economics, 68, 2721-2728.

https://doi.org/10.1016/j.ecolecon.2009.05.008

[8] Kumar, V., Kumar, R., Singh, J. and Kumar, P. (2019) Contaminants in Agriculture and Environment: Health Risks and Remediation. Agriculture and Environmental Science, India. https://doi.org/10.26832/AESA-2019-CAE

[9] Kaur, H. and Garg, H. (2014) Pesticides: Environmental Impacts and Management Strategies. In: Soloneski, S., Ed., Pesticides-Toxic Aspects, IntechOpen, London. https://doi.org/10.5772/57399

[10] Jallow, M., Awadh, D., Albaho M., Devi, V. and Thomas, B. (2017) Pesticide Risk Behaviors and Factors Influencing Pesticide Use Among Farmers In Kuwait. Science of the Total Environment, 574, 490-498. https://doi.org/10.1016/j.scitotenv.2016.09.085

[11] Kim, H., Räsänen, K., Chae, H., Kim, K., Kim, K. and Lee, K. (2016) Farm Work-Related Injuries and Risk Factors in South Korean Agriculture. Journal of Agromedicine, 21, 345-352. https://doi.org/10.1080/1059924X.2016.1211573

[12] Mohanty, M., Behera, B., Jena, S., Srikanth, S., Mogane, C., Samal, S., et al. (2013) Knowledge Attitude and Practice of Pesticide Use among Agricultural Workers in Puducherry, South India. Journal of Forensic and Legal Medicine, 20, 1028-1031. https://doi.org/10.1016/j.jflm.2013.09.030

[13] Visram, A. and Wilson, D. (2012). A Descriptive-Comparative Study of Medications Used by Older People Prior to and Following Admission to a Continuing Care Facility. Open Journal of Nursing, 2, 8-14. https://doi.org/10.4236/ojn.2012.21002

[14] Healey, J.F. (2009) Statistics: A Tool for Social Science Research. Michele Sordi, USA.

[15] Vaske, J. (2008) Survey Research and Analysis: Applications in Parks, Recreation, and Human Dimensions. Venture Publishing, Inc., State College.

[16] Nyatuame, M. and Ampiaw, F. (2015) Assessment of Farmer's Awareness on the Safety andHealth Implications on the Use of Agrochemicals: A Case Study of Afife Rice Farmin Ghana. Asian Journal of Agricultural Extension, Economics \& Sociology, 7, 1-9. https://doi.org/10.9734/AJAEES/2015/19594

[17] Robertson, R. and Turner, B. (1989) Talcott Parsons and Modern Social Theory-An Appreciation. Theory, Culture \& Society, 6, 539-558.

https://doi.org/10.1177\%2F026327689006004002

[18] Daly, J., Willis, K., Small, R., Green, J., Welch, N., Kealy, M. and Hughes, E. (2007) A Hierarchy of Evidence for Assessing Qualitative Health Research. Journal of Clinical Epidemiology, 60, 43-49. https://doi.org/10.1016/j.jclinepi.2006.03.014

[19] Paladan, N. (2019) Uplifting Farmers Communities: A Training Needs Assessment. International. Journal of Environmental \& Agriculture Research, 5, 18-28. 
[20] Hoppin, J., Umbach, D., London, S., Alavanja, M. and Sandler, D. (2002) Chemical Predictors of Wheeze among Farmer Pesticide Applicators in the Agricultural Health Study. American Journal of Respiratory and Critical Care Medicine, 165, 683-968. https://doi.org/10.1164/ajrccm.165.5.2106074

[21] Kolstrup, C., Kallioniemi, M., Lundqvist, P., Kymäläinen, H., Stallones, L. and Brumby, S. (2013) International Perspectives on Psychosocial Working Conditions, Mental Health, and Stress of Dairy Farm Operators. Journal of Agromedicine, 18, 244-255. https://doi.org/10.1080/1059924X.2013.796903

[22] Moradhasel, S., Mirakzadeh, A., Rostami, F. and Ataei, P. (2018) Assessment of the Farmers' Awareness about Occupational Safety and Health and Factors Affecting it; A Case Study in Mahidasht, Kermanshah Province. Health Education and Health Promotion, 6, 23-39. https://doi.org/10.29252/HEHP.6.1.23

[23] Anyim, A. and Aghale, D. (2017) Review on Pesticides Safety on Stored Products in Nigeria. Journal of Agricultural Science and Practice, 2, 90-96. https://doi.org/10.31248/JASP2017.060

[24] Mequanint, C., Getachew, B., Mindaye, Y., Amare, D., Guadu, T. and Dagne, H. (2019). Practice towards Pesticide Handling, Storage and Its Associated Factors among Farmers Working in Irrigations in Gondar Town, Ethiopia. BMC Research Notes, 12, Article No. 709. https://doi.org/10.1186/s13104-019-4754-6 